\title{
MICHAEL G. CARTER: A BIBLIOGRAPHY
}

\section{8}

1968. A Study of Sībawaihi's Principles of Grammatical Analysis. D. Phil. Dissertation, University of Oxford.

1971

1971. 'The Kātib in Fact and Fiction', Abr-Nahrain. An Annual Published by the

Department of Middle Eastern Studies, University of Melbourne 11: 42-55.

1972

1972. 'Les origines de la grammaire arabe', Revue des études islamiques 40: 69-97.

1972. "Twenty Dirhams' in the Kitāb of Sỉbawayhi', Bulletin of the School of Oriental and African Languages 35: 485-96.

1973

1973. 'An Arab Grammarian of the Eighth Century AD. A Contribution to the History of Linguistics', Journal of the American Oriental Society 93/2: 146157.

An Arabic translation of the above article made by Muhammad Rašīd alHamzāwī appeared in Dawliyyāt al-Jāmic a l-Tūnisiyya 22 (1983): 223-45.

1973. 'Șarf et Hilāf, contribution à l'histoire de la grammaire arabe', Arabica 20: 292-304.

1974. 'Two Works Wrongly Attributed to Early Arab Grammarians', Islamic Quarterly 18: 11-13.

1974. Review of N. S. Doniach, The Oxford English-Arabic Dictionary, Oxford, 1972, M. E. Studies 10, 351-2.

1974. Review of S. A. Hanna and N. Greis, Beginning Arabic. A Linguistic Approach from Cultivated Cairene to Formal Arabic, Leiden 1972, Bulletin of the School of Oriental and African Studies 37: 461-2.

1975

1975. 'A Note on Classical Arabic Exceptive Sentences', Journal of Semitic Studies 20: 69-72.

1975. 'Some Suggestions for a History of Arabic Grammar', Actes XXIX Congrès International des Orientalistes, 1975: Études arabes et islamiques II. Langue et littérature, 36-9. Paris: L'Asiathèque.

1976

1976. 'The Origins of Arabic Grammar', Proceedings of the 28th International Congress of Orientalists, Canberra 1971. Sydney.

1976. Review of S. M. Stern, Hispano-Arabic Strophic Poetry, Studies by Samuel Miklos Stern, ed. L. P. Harvey, Oxford, 1974. Journal of the Australasian Universities Modern Language Association 46: 327-8.

1976. Review of J. I. Smith, An Historical and Semantic Study of the Term Islam as Seen in a Sequence of Quran Commentaries, Harvard University Press, 1975, Journal of Religious History (Australia) 9: 430-1. 
1979. 'A $16^{\text {th }}$-Century Grammatical Experiment that Failed', Arabica 26: 26773.

\section{0}

1980. 'Sībawayhi and Modern Linguistics', Histoire, Épistémologie, Langage (Lille) 2: 21-6.

\section{1}

1981. Arab Linguistics: An Introductory Classical Text with Translation and Notes. Amsterdam and Philadelphia: Benjamins.

1981. 'The Use of Proper Names as a Testing Device in Sībawayhi's Kitāb', Historiographia Linguistica, 8/2-3: 345-56 (also published in Kees Versteegh et al. (eds.). 1983. The History of Linguistics in the Near East, 109-20. Amsterdam and Philadelphia: Benjamins).

\section{2}

1982. 'Remarks on M. B. Schub: 'A Sublime Subtlety', Zeitschrift für arabische Linguistik 7: 79-81.

\section{3}

1983. 'Language Control as People Control in Medieval Islam: the Aims of the Grammarians in their Cultural Context', Al-Abhâat 31: 76-84.

1983. Review of M. Bakalla, Ibn Jinnī, an Early Muslim Phonetician. An Interpretative Study of His Life and Contributions to Linguistics, London and Taipei 1982. Historiographia Linguistica 10: 109-11.

\section{4}

1984. 'Linguistic Science and Orthodoxy in Conflict: the Case of al-Rummānī', Zeitschrift für Geschichte der arabisch-islamischen Wissenschaften 1: 21232.

\section{5}

1985. 'When Did the Arabic Word Nahw First Come to Denote Grammar?', Language and Communication 5: 265-77.

1985. 'The Term Sabab in Arabic Grammar', Zeitschrift für arabische Linguistik 15: 53-66.

\section{6}

1986. Review of Kees Versteegh, Pidginization and Creolization: the Case of Arabic, Amsterdam and Philadelphia 1984. Australian Journal of Linguistics 6: 131-5.

1987

1987/1988. 'Arab Linguistics and Arabic Linguistics', Zeitschrift für Geschichte der arabisch-islamischen Wissenschaften 4: 205-18.

1987. 'When Did the Word Nahw Come to Denote Grammar?', in H. Aarsleff, L. G. Kelly, and H.-J. Niederehe (eds.). Papers in the History of Linguistics: Proceedings of the Third International Conference on the History of the Language Sciences (ICHoLS III), Princeton 1984, 85-6. Amsterdam and Philadelphia: Benjamins.

1987. Review of Ariel Bloch, Studies in Arabic Syntax and Semantics, Wiesbaden 1986. Journal of the American Oriental Society 107/4: 812-4. 
1987. Review of H. Schönig, Das Sendschreiben des 'Abdalhamīd b. Yahyā (gest. 132/750) an den Kronprinzen 'Abdallāh b. Marwān II, Stuttgart 1985, Journal of Arabic Literature 18: 121-3.

\section{8}

1988. 'The Grammatical Riddles of ${ }^{\mathrm{c}} \mathrm{Al} \overline{\mathrm{l}} \mathrm{b}$. Muhammad ibn $\mathrm{Ya}^{\mathrm{c}}{ }^{\mathrm{1}} \mathrm{sh}$ ', in A. K. Irvine, R. B. Sergeant, and G. Rex Smith (eds.). A Miscellany of Middle Eastern Articles: Memorial Volume for Thomas Muir Johnstone, 178-88. London: Longman.

1988. Article 'Ash' ${ }^{\mathrm{a}} \mathrm{a} \overline{1}$ ', in Great Lives from History, Ancient and Medieval Series, 243-8. Pasadena.

\section{9}

1989. 'The Arabic and Medieval Latin Grammatical Terms for 'governing", in K. D. Lutz (ed.). Speculum historiographicae linguisticae. Kurzbeiträge der IV. internationalen Konferenz zur Geschichte der Sprachwissenschaften (ICHoLS IV), Trier, 24-27 August 1987, 29-36. Mūnster: Nodus Publikationen.

1989. Review of Joel Kraemer, Humanism in the Renaissance of Islam: The Cultural Revival during the Buyid Age, Leiden 1986. Journal of the American Oriental Society 109/2: 304-5.

1989. Review of The History of al-Tabarī (SUNY Press, various translators), Journal of the Iranian Society 22: 137-41.

\section{0}

1990. Studies in the History of Arabic Grammar, II. Proceedings of the 2nd Symposium on the History of Arabic Grammar, Nijmegen, 27 April-1 May 1987, co-ed. Kees Versteegh, Amsterdam and Philadelphia: Benjamins.

1990. 'Qāḍ̂̄, Qāḍi, Qāḍ: Which Is the Odd Man Out?', in M. G. Carter and K. Versteegh (eds.). Studies in the History of Arabic Grammar, II. Proceedings of the 2nd Symposium on the History of Arabic Grammar, Nijmegen, 27 April-1 May 1987, 73-90. Amsterdam and Philadelphia: Benjamins.

1990. 'Arabic Grammar', in M. J. L. Young et al. (eds.). Cambridge History of Arabic Literature. Religion, Learning and Science in the ${ }^{c}$ Abbasid Period, 118-38. Cambridge: Cambridge University Press.

1990. 'Arabic Lexicography', in M. J. L. Young et al. (eds.). Cambridge History of Arabic Literature. Religion, Learning and Science in the ${ }^{c}$ Abbasid Period, 106-17. Cambridge: Cambridge University Press.

1990. Review of M. A. Yousef, Das Buch der schlagfertigen Antworten, (Ibn Abī ${ }^{\mathrm{c}}$ Awn), Berlin, 1988. Middle East Studies Association Bulletin 24: 2535.

1990. Review of A. Bergter, Das Kapital 'inna wa-ahawātuhā' aus dem 'Manhağ as-sālik' des Grammatikers Abū Hayyān al-Giarnāțī (1256-1344), Hildesheim 1988. British Association of Middle Eastern Studies Bulletin 17: 210-1.

\section{1}

1991. 'The Ethical Basis of Arabic Grammar', Al-Karmil 12: 9-23. 
1991. 'Elision', in K. Dévényi and T. Iványi (eds.). Proceedings of the Colloquium on Arabic Grammar, 121-41. Budapest: Eötvös Loránd University and Csoma de Körös Society (= Budapest Studies in Arabic 3-4).

1991. 'Ibn Jinnī's Axiom 'the Adventitious Determines the Rule', in A. Kaye (ed.) Semitic Studies in Honor of Wolf Leslau on the Occasion of His EightyFifth Birthday, I: 199-208, Wiesbaden.

1991. Review of Jonathan Owens, The Foundations of Grammar. An Introduction to Medieval Arabic Grammatical Theory, Amsterdam and Philadelphia 1988, Journal of the American Oriental Society 111/2: 395-7.

1991. Review of A. Arazi, La Réalité et la fiction dans la poésie arabe ancienne, Paris 1989, Middle East Studies Association Bulletin 25: 239-40.

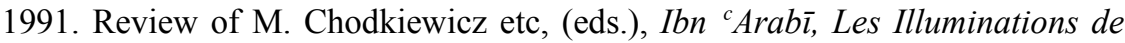
La Mecque, Paris 1988, Middle East Studies Association Bulletin 25: 245-6.

1992

1992. Review of Mushira Eid (ed.), Perspectives on Arabic Linguistics, I: Papers From the First Annual Symposium on Arabic Linguistics, Amsterdam and Philadelphia 1990 and of Mushira Eid and John J. McCarthy (eds.), Perspectives on Arabic Linguistics, II: Papers From the Second Annual Symposium on Arabic Linguistics, Amsterdam and Philadelphia 1990, Journal of the American Oriental Society 112/1: 143.

1992. Review of G. Bohas, J.-P. Guillaume, D. E. Kouloughli, The Arabic Linguistic Tradition, London 1990, Historiographia Linguistica 19: 361-7.

1992. Review of D. Agius, The Study of Arabic in Malta, 1632-1915, Louvain 1990, Middle East Studies Association Bulletin 26: 236-7.

1993

1993. 'Language and law in the Șạhibī of Ibn Fāris', Zeitschrift für arabische Linguistik 25: 139-47.

1993. 'Probleme bei der Übersetzung von Fachsprache am Beispiel des Arabischen', in A. Frank, K. Maaß, F. Paul, and H. Turk (eds.). Übersetzen, verstehen, Brūcken bauen: Geisteswissenschaftliches und literarisches Übersetzen im internationalen Kulturaustausch, 130-41. Berlin: Erich Schmidt Verlag.

1994

1994. 'Writing the History of Arabic Grammar', Historiographia Linguistica 21/3: 385-414.

1994. Article 'Sabab', in Encyclopaedia of Islam (2nd edition), 8: 666. Leiden: Brill.

1994. Review of J. van Ess, Theologie und Gesellschaft im 2. und 3. Jahrhundert Hidschra, Bände I-II, Berlin, 1991-2. Middle East Studies Association Bulletin 28/2: 241-2.

1994. Review of Jonathan Owens, Early Arabic Grammatical Theory: Heterogeneity and Standardization, Amsterdam and Philadelphia 1990. Journal of the American Oriental Society 114/3: 472-5.

1994. Review of M. Sawaie, Risāla fì taḥqīq tac rīb al-kalima al- ${ }^{\circ} a^{c} j a m \bar{y} y a$, Damascus, 1991, Al-Arabiyya 27: 79-82. 
1994. Review of Christine Schirrmacher, Mit den Waffen des Gegners. Christlich-muslimische Kontroversen im 19. und 20. Jahrhundert, Berlin 1992. Middle East Studies Association Bulletin 28: 109-10.

1994. Articles 'Al-Halīl ibn Ahmad' and 'Sībawayhi', in Encyclopaedia of Language and Linguistics, ed. R. E. Asher, J. M. Y. Simpson, Oxford, New York, Seoul, Tokyo, I: 71; VII: 3882-3.

1995

1995. 'Predication Tests, Copula, and a Possible Link with Ašcarism', in A. Fodor (ed.). Proceedings of the 14th Congress of the Union Européenne des Arabisants et Islamisants, 23-36. (= Budapest Studies in Arabic 13-14).

1995. 'Workshop on Grammatical Terminology', in N. Anghelescu and A. Avram (eds.). Proceedings of the Colloquium on Arabic Linguistics, Bucharest, August 29-September 2, 1994, 47-53. Bucharest: University of Bucharest Center for Arabic Studies.

1995. 'Arabic Literature', in D. C. Greetham (ed.). Scholarly Editing. A Guide to Research, 546-74. New York: The Modern Language Association of America.

1995. Article 'Șahīḥ (3. in grammar)', in Encyclopaedia of Islam (2nd edition), 8: 835. Leiden: Brill.

1995. Review of A. A. al-Nassir, Sībawayh the Phonologist, London 1993. Bulletin of the School of Oriental and African Studies 58/2: 359-60.

1995. Review of F. E. Peters (ed.), A Reader on Classical Islam, Princeton 1994. Journal of the American Oriental Society 115/1: 148-51.

1995. Articles 'Arabic', 'Heresy (Islam)', The HarperCollins Dictionary of Religion, ed. J. Z. Smith, Area Editor R. C. Martin, San Francisco, 65-6, 414-5.

1996

1996. 'Signs of Change in Egyptian Arabic', in A. Elgibali (ed.). Understanding Arabic, Essays in Contemporary Arabic Linguistics in Honor of El-Said Badawi, 137-43. Cairo: American University in Cairo Press.

1996. Article 'Shart', in Encyclopaedia of Islam (2nd edition), 9: 360. Leiden: Brill.

1996. Review of Manfred Ullmann, Launuhū ilā l-humrati mā huwa, Munich 1994. Journal of Semitic Studies 41/1: 173-5.

1997

1997. 'Analogical and Syllogistic Reasoning in Grammar and Law', in P. G. Riddell and T. Street (eds.). Islam: Essays on Scripture, Thought and Society: a Festschrift in Honour of Anthony H. Johns, 104-12. Leiden: Brill.

1997. 'Copula in Arabic Grammar', in W. Madelung et al. (eds.). Proceedings of the $17^{\text {th }}$ Congress of the Union Européenne des Arabisants et Islamisants, 37-45. St. Petersburg.

1997. 'Humanism and the Language Sciences in Medieval Islam', in A. Afsaruddin and A. Zahneiser (eds.). Humanism, Culture, and Language in the Near East. Studies in Honor of Georg Krotkoff, 27-38. Winona Lake: Eisenbrauns. 
1997. 'The Platonic Edition. Some Consequences of Computer Editing for Textbased Scholarship in Arabic Grammar', Manuscripta Orientalia 3/4: 54-8.

1997. Article: 'Sībawayhi', in Encyclopaedia of Islam (2nd edition), 9: 524-31. Leiden: Brill.

1997. Review of Adrian Gully, Grammar and Semantics in Medieval Arabic, Richmond 1995. British Journal of Middle Eastern Studies 24/1: 137-9.

\section{8}

1998. 'Another Khalil: Courtier, Teacher and Sage' in K. Ryding (ed.). Early Medieval Arabic. Studies on al-Khalīl ibn Ahmad, 16-43. Washington DC: Georgetown University Press.

1998. 'Infinity and Lies in Medieval Islam', in U. Vermeulen and D. De Smet (eds.). Philosophy and Arts in the Islamic World, 233-42. Leuven: Peeters.

1998. 'The Term mudāri ${ }^{c}$ in the Kitāb of Sỉbawayhi', in K. Dévényi and T. Iványi (eds.), Proceedings of the Arabic and Islamic Sections of the 35th International Congress of Asian and North African Studies (ICANAS) Part One, Linguistics, Literature, History, 3-14 (= Budapest Studies in Arabic 1920).

1998. Articles 'Tafụīl', 'Tāhin b. Aḥmad b. Bābashādh', 'Tamthīl', 'Ta 'rīf', in Encyclopaedia of Islam (2nd edition), vols. 10: 82; 10: 102; 10: 179-80; 10: 240-1. Leiden: Brill.

1998. Articles: ' Abd al-Qādir ibn ${ }^{~}$ Umar al-Baghdādī, I: 15-6; abjad, I: 22-3; Abū ${ }^{c} A m r$ ibn al- ${ }^{c} A l \bar{a}^{0}$, I: 26; al-Anbārī, I: 89-90; al-Așma ${ }^{c} \overline{1}$, I: 110; alAstarābādhī, I: 110-11; al-Farrā̄o , I: 122; al-Fīrūzābādī, I: 234; grammar and grammarians, I: 254-7; Ibn Ājurrūm, I: 308-9; Ibn al-Anbārī, I: 310; Ibn Durayd, I: 322; Ibn Fāris al-Lughawī, I: 325; Ibn al-Ḥājib, I: 328; Ibn Hishām al-Naḥwīi, I: 335-6; Ibn Jinnī, I: 339-40; Ibn Kaysān, I: 342; Ibn Mālik, I: 347-8; Ibn Manșūr, I: 348; Ibn al-Sikkīt, I: 373; Jakhjakh, I: 410; al-Jawālīqī, I: 413-4; al-Jawharī, I: 414; lexicography (medieval), II: 467-9; lexicography (modern), II: 469-70; al-Riyāshī, II: 664; Sībawayhi, II: 718; al-Sijistānī, II: 721; Tha ${ }^{c}$ lab, II: 765-6; al-Zabīdī, II: 817; al-Zajjājīi, II: 820, in P. Starkey and J. Meisami (eds.), Encyclopedia of Arabic Literature. London and New York: Routledge.

1998. Article 'Ebn Kalawayh', Encyclopaedia Iranica 8: 32. London and New York: Routledge.

1998. Review of Christiane Gille, Das Kapital al-Maușūl (Das Relativum) aus dem Manhağ as-sālik des Grammatikers Abū Haijāan al-Ġarnāțī (12561344), Hildesheim 1995. Journal of Semitic Studies 43/1: 192-4.

1998. Review of Rafael Talmon, Arabic Grammar in its Formative Age. Kitāb al- ${ }^{c}$ Ayn and its Attribution to Halīl b. Ahmad, Leiden 1997. Zeitschrift für Geschichte der arabisch-islamischen Wissenschaften 12: 340-4.

1998. Review of Kees Versteegh, The Arabic Language, Edinburgh 1997. Bulletin of the School of Oriental and African Studies 61/3: 550-1.

1998. Review of Kees Versteegh, The Explanation of Linguistic Causes: azZağğăğ̋̀ı’s Theory of Grammar. Introduction, Translation, Commentary, 
Amsterdam and Philadelphia 1995. Bulletin of the School of Oriental and African Studies 61/2: 330-1.

1998. Review of Elie Wardini (ed.), Built on Solid Rock. Studies in Honour of Professor Ebbe Egede Knudsen on the Occasion of his 65th Birthday April 11th 1997, Oslo 1997. Norsk lingvistisk tidsskrift 16/2: 285-6.

1999

1999. 'The Struggle for Authority. A Re-examination of the Basran and Kufan Debate', in L. Edzard and M. Nekroumi (eds.). Tradition and Innovation. Norm and Deviation in Arabic and Semitic Linguistics, 55-70. Wiesbaden: Harrassowitz.

1999. Review of Monique Bernards, Changing Traditions: al-Mubarrad's Refutation of Sïbawayhi and the Subsequent Reception of the Kitāb, Leiden 1997. Journal of Semitic Studies 44/2: 333-5.

1999. Review of Arie Levin, Arabic Linguistic Thought and Dialectology, Jerusalem 1998. Journal of Islamic Studies 10/3: 329-31.

2000

2000. 'The Development of Arabic Linguistics after Sībawayhi: Basra, Kufa and Baghdad', in S. Auroux et al. (eds.) History of the Language Sciences. An International Handbook on the Evolution of the Study of Language from the Beginnings to the Present, 263-72. Berlin: Walter de Gruyter.

2000. 'Ușūl', in Encyclopaedia of Islam (2nd edition), 10: 928-9. Leiden: Brill.

2000. Review of John Mace, Arabic Grammar. A Reference Guide, Edinburgh 1998. Bibliotheca Orientalis 57/1-2: 195-8.

2001

2001. 'A Missing Link between Law and Grammar: the Intișār of Ibn Wallād', Arabica 48: 51-65.

2001. 'Arabic', in J. Garry and C. Rubino (eds.). Facts about the World's Languages, 23-7. New York: H. W. Wilson.

2001. Article 'Wașl', in Encyclopaedia of Islam (2nd edition), 10: 172-3. Leiden: Brill.

2001. 'Arabic Verbs' (with D. W. Rogers). Derek Rogers Professional Software, 2001.

2001. Review of Hartmut Bobzin, Der Koran im Zeitalter der Reformation. Studien zur Frūhgeschichte der Arabistik und Islamkunde in Europa, Beirut und Stuttgart, 1995. Bibliotheca Orientalis 58/1-2: 265-8.

2001. Review of Amidu Sanni, The Arabic Theory of Prosification and Versification, Beirut 1998. Journal of the Oriental Society of Australia 32/33: 2259.

2001. Review of Yasir Suleiman, Arabic Grammar and Linguistics, Richmond 1999. Historiographia Linguistica 28/1/2: 221-5.

2002

2002. 'Patterns of Reasoning: Sībawayhi's Concept of the hạl', Proceedings of the 20th Congress of the Union Européenne des Arabisants et Islamisants, 315 (= Budapest Studies in Arabic 24-25). 
2002. Article 'Zarf', in Encyclopaedia of Islam (2nd edition), 11: 459 Leiden: Brill.

2002. Article 'Linguistica e lessicografia', in S. Petruccioli (ed.). Storia della Scienza, vol. III, 76-85. Rome: Enciclopedia italiana.

2002. Review of Mohamed M. Yunis Ali, Medieval Islamic Pragmatics. Sunni Legal Theorists' Models of Textual Communication, Richmond 2000. Islamic Law and Society 9/2: 275-80.

2002. Review of Sven-Olof Dahlgren, Word Order in Arabic, Gothenburg 1998. Journal of the American Oriental Society 122/1: 89-91.

2002. Review of Werner Diem, fa-waylun li-l-qāsiyati qulūbuhum. Studien zum arabischen adjektivischen Satz, Wiesbaden 1998. Bibliotheca Orientalis 59: 671-74.

2002. Review of Dmitry Frolov, Classical Arabic Verse, History and Theory of ${ }^{c}$ Arū , Leiden 2000. Journal of Islamic Studies 13: 72-5.

2003

2003. 'Legal Schools and Grammatical Theory', in S. Evstatiev (ed.). Arabistika $i$ Isliamoznanie. Tom 2. Studi po sluchai 60-godishninata na dots. d.f.n. Penka Samsareva, 177-83. Sofia: St. Clement Ochridski University.

2003. 'The Scholar as Dragoman: the A. R. Davis Memorial Lecture, Oriental Society of Australia, July 2003', Journal of the Oriental Society of Australia 35: $1-19$.

2003. 'Talking with and about God: Adam and the Arabic Language', in A. Pellitteri (ed.). Mağăaz. Culture e contatti nell'area del Mediterraneo. Il ruolo dell'Islam, 197-208. Annali della Facoltà di Lettere e Filosofia dell'Università di Palermo. La Memoria 15. Palermo.

2003. Article: 'Lafz', in Encyclopaedia of Islam (2nd edition), 12 (supplement): 545-6. Leiden: Brill.

2003. Review of Albert Arazi et al. (eds.), Compilation and Creation in Adab and Luga: Studies in Memory of Naphtali Kinberg (1948-1997), Winona Lake 1999 (= Israel Oriental Studies 19). Journal of the American Oriental Society 123/2: 458-9.

2003. Review of Gert Borg and Ed de Moor (eds.), Representations of the Divine in Arabic Poetry, Amsterdam and Atlanta, Ga., 2001. Journal of Islamic Studies 14/2: 208-11.

\section{4}

2004. Modern Written Arabic, a Comprehensive Grammar (co-authors Elsaid Badawi and Adrian Gully). London and New York: Routledge.

2004. Sïbawayhi. Oxford: I.B. Tauris and Oxford University Press.

2004. 'Adam and The Technical Language of Medieval Islam', in R. Arnzen and J. Thielmann (eds.). Words, Texts and Concepts. Cruising the Mediterranean Sea. Studies on the Sources, Contents and Influences of Islamic Civilization and Arabic Philosophy and Science Dedicated to Gerhard Endress on his $65^{\text {th }}$ Birthday, 439-54. Leuven: Peeters. 
2004. 'Arabisk - det klassiske kulturspråket', in K. Gammelgaard, G. Mejdell, and R. Svarverud (eds.). Standardspråk Underveis, 81-94. Oslo: Unipub forlag.

2004. 'Prolégomènes au Kitāb de Sībawayhi' (co-author Georges Bohas), Langues et littératures du monde arabe 5: 43-59.

2004. Review of Joyce Åkesson, Arabic Morphology and Phonology, Based on the Marāh al-arwāḥ by Ahmad b. ${ }^{c}$ Alī b. Mas ${ }^{c} \bar{u} d$. Presented with an Introduction, Arabic Edition, and English Translation and Commentary, Leiden 2001. Bibliotheca Orientalis 61/5-6: 634-8.

\section{5}

2005. 'The Indeterminacy of the Qur`ān', Folia Orientalia 41: 9-24.

2005. Article 'Sībawayhi', in M. Cooperson and S. Toorawa (eds.) Arabic Literary Culture, 500-925 (Dictionary of Literary Biography, vol. 311), 325-31. Detroit.

2005. Article 'Arabic Traditional Grammar' in The Encyclopedia of Linguistics, ed. Philipp Strazny, New York/Oxford, I: 78-9.

\section{6}

2006. 'The Qur`ān and The Authority of Arab-Islamic Linguistics', in L. Edzard and J. Retsö (eds.). Current Issues in the Analysis of Semitic Grammar and Lexicon II, 11-23. Wiesbaden: Harrassowitz.

2006. 'Approaches to The Technical Terms of Arabic Grammar', in B. MichalakPikulska, and A. Pikulska (eds.). Authority, Privacy and Public Order in Islam. Proceedings of the 22nd Congress of L'Union Européenne des Arabisants et Islamisants, 459-67. Leuven/Dudley, MA: Peeters. (= Orientalia Lovanensia Analecta, 148).

2006. English translation of 'Les Origines de la grammaire arabe' (1972), in R. Baalbaki (ed.). The Early Islamic Grammatical Tradition. Burlington, VT: Ashgate.

2006. 'Foreign Vocabulary', in A. Rippin et al. (eds.). Blackwell's Companion to the Qur'ān, 20-139. Oxford: Blackwell.

2006. Articles 'Grammarians and The Grammatical Tradition', 'Humanism', 'Sībawayhi', in J. Meri et al. (eds). Medieval Islamic Civilization, an Encyclopedia. London and New York: Routledge.

2007

2007. Modern Written Arabic. A Comprehensive Grammar (co-authors Elsaid Badawi and Adrian Gully). 2nd edn with corrections. London and New York: Routledge.

2007. 'Pragmatics and Contractual Language in Early Arabic Grammar and Legal Theory', in E. Ditters and H. Motzki (eds.). Approaches to Arabic Linguistics. Presented to Kees Versteegh on The Occasion of His Sixtieth Birthday, 25-44. Leiden and Boston: Brill.

2007. Review of Richard M. Frank: Philosophy, Theology and Mysticism in Medieval Islam, Dimitri Gutas (ed.), Texts and Studies on The Development and History of Kaläm, vol. 1, Burlington, VT 2005. Journal of Islamic Studies 18: 406-8. 
2007. Articles on: elision, II: 16-18; grammatical tradition: history, II: 182-91; ${ }^{\circ}$ iḍmār (co-author Kees Versteegh), II: 300-2; ism al-făc ${ }^{\mathrm{c}} \mathrm{ll}$, II: 429-32, in K. Versteegh et al. (eds.). Encyclopaedia of Arabic Language and Linguistics. Volume II. Eg-Lan. Leiden: Brill.

\section{8}

2008. 'More Infinity, More Lies: History, Truth and Change in Medieval Islam', in K. d'Hulster and J. Van Steenbergen (eds.). Continuity and Change in the Realms of Islam: Studies in Honour of Professor Urbain Vermeulen, 105-15. Leuven: Peeters.

2008. Articles 'mādīi/muḍāri' ', 'parts of speech', in K. Versteegh et al. (eds.). Encyclopaedia of Arabic Language and Linguistics. Volume III: Lat-Pu. Leiden: Brill.

\section{Forthcoming:}

History of the Arabic Language. Cambridge: Cambridge University Press.

Article 'sabab', in K. Versteegh et al. (eds), Encyclopaedia of Arabic Language and Linguistics, vol. 4. Leiden: Brill.

Article 'c Abd al-Qādir ibn 'Umar al-Baghdādī', in J. Lawry and D. Stewart (eds.). Dictionary of Literary Biography.

Review of Rafael Talmon, Eighth-Century Iraqi Grammar. A Critical Exploration of Pre-Halīlian Arabic Linguistics, Winona Lake 2003, Bibliotheca Orientalis.

Article 'Muslim Education', Diogenes.

Article 'Mystical Grammar or Grammatical Mysticism? A Șūfĩ Commentary on The Äjurrümiyya', in Monika Gronke and Marco Schöller (eds.), Festschrift for Werner Diem.

Article 'Kitāb Sībawayhi', in G. J. Roper (ed.), The Oxford Companion to the Book, Oxford.

'Sentence Types in Grammar, Law and Philosophy', in Proceedings of the 23rd Congress of the Union Européenne des Arabisants et Islamisants, Sassari, August 2006. Leuven.

Review of Werner Diem, Wurzelrepetition und Wunschsatz: Untersuchungen zur Stilgeschichte des arabischen Dokuments des 7. bis 20. Jahrhunderts, Harrassowitz, Wiesbaden 2005, Journal of Islamic Studies.

Review of Richard M. Frank, Early Islamic Theology: the Muctazilites and al$A s h^{c}$ ari, Texts and Studies on the Development and History of Kalam, vol. II, Ashgate, Aldershot 2007, Journal of Islamic Studies.

Review of Ramzi Baalbaki, The Legacy of the Kitāb. Sibawayhi's Analytical Methods within the Context of the Arabic Grammatical Theory, Brill, Leiden 2008, Journal of the American Oriental Society.

\section{Online publications:}

www.arts.usyd.edu.au/research_projects/sibawiki/homepage/ [Last accessed: 6 Nov 2008].

www.hf.uio.no/ikos/studier/fag/arabisk/sibawayhi/HomePage/ [Last accessed: 6 Nov 2008]. 